\title{
Stock identification of neon flying squid (Ommastrephes bartramii) in the North Pacific Ocean on the basis of beak and statolith morphology
}

\author{
Zhou Fang ${ }^{1}$, Bilin Liu ${ }^{1,2,3}$, Jianghua $\mathrm{Li}^{1,2,3}$, Hang Su ${ }^{1}$, Xinjun Chen ${ }^{1,2,3}$ \\ ${ }^{1}$ College of Marine Sciences, Shanghai Ocean University, Hucheng Ring Road 999, Lingang New City, Shanghai 201306, \\ China. E-mail: xjchen@shou.edu.cn \\ ${ }^{2}$ The Key Laboratory of Shanghai Education Commission for Oceanic Fisheries Resources Exploitation, 999 Hucheng \\ Ring Road, Shanghai 201306, China. \\ ${ }^{3}$ The Key Laboratory of Sustainable Exploitation of Oceanic Fisheries Resources, Ministry of Education, 999 Hucheng \\ Ring Road, Shanghai 201306, China.
}

\begin{abstract}
Summary: Cephalopods are becoming increasingly important in global fisheries as a result of increased landings and are playing an important ecological role in the trophic dynamics of marine ecosystems. Ommastrephes bartramii is a pelagic cephalopod species with two widely distributed spawning stocks in the North Pacific Ocean. It is also a major fishing target for the Chinese squid jigging fleets. Successful separation of these two spawning stocks is critical to fisheries management, but tends to be challenging because of their similar morphology. In this study we attempted to identify the stocks based on discriminant analyses of 9 morphological variables of statolith and 12 variables of beaks measured for $O$. bartramii samples in the North Pacific. A significant difference was revealed in the standardized beak and statolith variables between sexes in the northeast $(\mathrm{NE})$ stock $(\mathrm{P}<0.05)$. The northwest $(\mathrm{NW})$ stock showed significant differences between sexes for all variables $(\mathrm{P}<0.05)$ except for upper wing length $(\mathrm{P}>0.05)$, whereas the NW stock showed no significant difference in either sex for the statolith variables $(P>0.05)$. The same sex also revealed different patterns with different hard structures between the two stocks. In t-tests females showed significant differences between stocks in statolith morphology $(\mathrm{P}<0.05)$ and beak morphology $(\mathrm{P}<0.05)$; males also showed this difference between cohorts in statolith variables $(\mathrm{P}<0.05)$ except dorsal dome length and wing length $(\mathrm{P}>0.05)$, but showed no difference between cohorts $(\mathrm{P}>0.05)$ in beak morphometric variables. With the combination of two standardized hard parts, correct classification of stepwise discriminant analysis (SDA) was raised by nearly $20 \%$ compared with using only one structure, although overlaps of the NW stock were still found in the scatter-plots. It is concluded that adding more appropriate hard structure variables will effectively increase the success of separating geographic stocks by the SDA method.
\end{abstract}

Keywords: Ommastrephes bartramii; statolith; beaks; morphology; geographic stock; stepwise discriminant analysis.

Identificación de las poblaciones de pota saltadora (Ommastrephes bartramii) en el Pacífico Norte a partir de la morfología de estatolitos y mandíbulas

Resumen: Los cefalópodos son cada vez más importantes en las pesquerías mundiales como consecuencia de su volumen de capturas, jugando un importante rol en la red trófica de los ecosistemas marinos. Ommastrephes bartramii es una especie de cefalópodo pelágico con dos poblaciones de desove de amplia distribución en el Pacífico Norte. Asímismo, es un importante objetivo de las flotas pesqueras chinas de potera automática. La adecuada identificación de sus dos poblaciones de desove es fundamental para la gestión de esta pesquería, siendo una difícil tarea debido a su morfología similar. En este estudio se pretende identificar los stocks en función de los análisis discriminantes de nueve variables morfológicas del estatolito y doce variables de las mandíbulas, obtenidas en muestras de O. bartramii del Pacífico Norte. Se hallaron diferencias significativas entre sexos en las variables mandíbula y estatolito para el stock del noreste (stock $\mathrm{NE})(\mathrm{P}<0.05)$. El stock del noroeste (stock NO) mostró diferencias significativas entre sexos en todas las variables $(\mathrm{P}<0.05)$ con excepción de la longitud del ala superior $(\mathrm{P}>0.05)$, las medidas del estatolito no mostraron diferencias significativas en ambos sexos para el stock NO $(\mathrm{P}>0.05)$. Para cada sexo, también se hallaron diferencias entre las estructuras duras de ambos stocks. Los tests T-Student mostraron diferencias entre las hembras de ambos stocks en relación a la morfología del estatolito $(\mathrm{P}<0.05)$ y la mandíbula $(\mathrm{P}<0.05)$, las muestras de los machos también mostraron estas diferencias en la morfología de los estatolitos $(\mathrm{P}<0.05)$, excepto la longitud dorsal del domo y la anchura del rostro $(\mathrm{P}>0.05)$, no observándose diferencias entre las cohortes de machos $(\mathrm{P}>0.05)$ en las variables morfométricas de la mandíbula entre los dos stocks. En comparación con el uso de una sola estructura dura, el estudio conjunto de ambas estructuras mediante análisis discriminante incrementó en cerca de un $20 \%$ la correcta asignación a los diferentes stocks, a pesar de algunos solapamientos observados en los diagramas de dispersión del stock NO. Se puede considerar que el empleo adicional de estructuras duras adecuadas aumentará la probabilidad de identificar los stocks mediante análisis discriminante.

Palabras clave: Ommastrephes bartramii; estatolito; mandíbula; morfología, stock; análisis discriminante.

Citation/Como citar este artículo: Fang Z., Liu B., Li J., Su H., Chen X. 2014. Stock identification of neon flying squid (Ommastrephes bartramii) in the North Pacific Ocean on the basis of beak and statolith morphology. Sci. Mar. 78(2): 239248. doi: http://dx.doi.org/10.3989/scimar.03991.06A 
Editor: R. Villanueva.

Received: December 5, 2013. Accepted: April 1, 2014. Published: June 6, 2014.

Copyright: (C) 2014 CSIC. This is an open-access article distributed under the Creative Commons Attribution-Non Commercial Lisence (by-nc) Spain 3.0.

\section{INTRODUCTION}

Neon flying squid, Ommastrephes bartramii, is widely distributed around the world's oceans extending from the subtropics to temperate waters in the northern and southern hemispheres except in equatorial waters (Rodhouse 2005, Lefkaditou et al. 2011). Despite its huge potential abundance, it only supports a commercial fishery in the northwest Pacific Ocean. The exploitation of this epipelagic species was started in 1974 (Chen et al. 2009), with roughly 200000 to $300000 \mathrm{t}$ landed during the 1980s by Japan, Korea and Taiwan (Burke et al. 1993). Mainland China started fishing this squid in 1993, and mainly fished in the western waters $160^{\circ}$ east of the North Pacific. Recently, commercial squid jigging vessels of mainland China have mainly fished in the areas $150^{\circ} \mathrm{E}$ to $170^{\circ} \mathrm{W}$ and $40^{\circ}$ to $46^{\circ} \mathrm{N}$ from May to October with annual catches of between 50000 and $100000 \mathrm{t}$.

The population structure of $O$. bartramii has been studied by many researchers for putative seasonal cohorts (Murata 1990, Murata and Hayase 1993), rates of infection by helminth parasites (Bower and Margolis 1991, Nagasawa et al. 1998) and mantle length distribution (Murata 1990, Yatsu et al. 1998a). Murakami et al. (1981) identified the four stocks based on the squid body sizes extra-large (LL), large (L), small (S) and extra-small (SS). Chen et al. (2002) found that two populations existed in the waters of $165^{\circ} \mathrm{E}$ westward through nine body variables based on the Grey System Theory. A geographic pattern of population genetic variability was observed in $O$. bartramii, with major genetic differentiation attributable to inconsistency in allele frequency distribution and in levels of genetic variation between the squid from the western and eastern parts of the species, which covers a wide area in the North Pacific Ocean (Katugin 2002). Generally, in the North Pacific, the population of $O$. bartramii mainly comprises two cohorts: a) the autumn cohort hatching from September to February and $b$ ) the winter-spring cohort hatching from January to May (Katugin 2002, Chen and Chiu 2003, Ichii et al. 2004, Bower et al. 2005, Chen et al. 2011). The autumn cohort consists of the central stock and east stock, which separate near $160^{\circ} \mathrm{W}$. The winter-spring cohort also comprises the west stock and central-east stock, which separate near $170^{\circ} \mathrm{E}$ (Ichii et al. 2004, Bower and Ichii 2005). Although these two cohorts overlap geographically, they have been caught in different areas at separate times (Bower and Ichii 2005). The autumn cohort (NE stock) distributed in the waters east of $170^{\circ} \mathrm{E}$ from May to June and the winter-spring cohort (NW stock) distributed in the waters west of $165^{\circ} \mathrm{E}$ from July to November have been the main fishing target for Chinese squid jigging fleets since 1998 (Chen and Chiu 2003, Wang and Chen 2005).
Stock identification is critical for an effective fishery management to avoid overfishing and promote the sustainable development of fisheries (Cadrin and Silva 2005). Stock structures are often identified and verified on the basis of their different life history strategies and genetic structures. However, morphometric traits are still often used in this field (Sajina et al. 2011). Traditional measurements are based on the conventional orthogonal method, which uses length and width to describe the variables for species with rigid body forms. Unlike fish and many crustaceans, squid have a flexible soft body without a hard surface structure. The cylindrical mantle cavity varies during locomotion and respiration, and the stretched arms and tentacles are also broken easily, often by hooks during the jigging capture process (Cabanellas-Reboredo et al. 2011, Kurosaka et al. 2012). Thus, measurements based on the soft parts of squid are challenging and frequently contain errors, and an alternative structure should be used to separate stocks on the basis of body morphology. However, these measurements are fairly reliable if the approach is correct, as in the studies of Loliginidae by Pierce et al. (1994) and of Ommastrephidae by Martínez et al. (2002).

Hard structures, including the statolith, beak (mandibular) and gladius (pen), which contain a series of ecological information during its mysterious life history, have gradually been used for their stable and constant configuration (Bizikov and Arkhipkin 1997, Piatkowski et al. 2001, Ikeda et al.2003, Jackson and Domeier 2003, Guerra et al. 2010, Ruiz-Cooley et al. 2013). As calcified structures embedded in cartilage, a pair of statoliths is an indispensable part of the acceleration receptor system that controls the movement and direction of the cephalopod (Hanlon and Messenger 1996, Arkhipkin and Bizikov 2000). They are also used in studies of species identification (Clarke 1978, Dommergues et al. 2000, Lombarte et al.2006), age estimation (Villanueva 1992, Sánchez 1995, Arkhipkin and Shcherbich 2012), growth pattern (Yatsu 2000, Yatsu et al. 1997) and trace elements (such as strontium) (Durholtz et al. 1997, Ikeda et al. 1996, 1997, Yatsu et al. 1998b) to determine life history and relevant environmental conditions. As the main feeding organ, the beak can be easily preserved, and is non-corroding, so it has been used in the studies of chemical structure (Miserez et al. 2010), aging and growth (Yatsu et al. 1997, Raya and Hernández-González 1998, Yatsu and Mori 2000, Raya et al. 2010, Castanhari and Tomás 2012, Perales-Raya et al. 2014), species identification (Smale et al. 1993), biomass estimation (Lu and Ickeringill 2002), trophic dynamics (Cherel and Hobson 2005, Cherel et al. 2009) and paralarval ontogeny (Uchikawa et al. 2009).

The measurement of hard structures has been the basis of these studies. Radial measurement is a simple way to analyse the relationship between statolith shape 


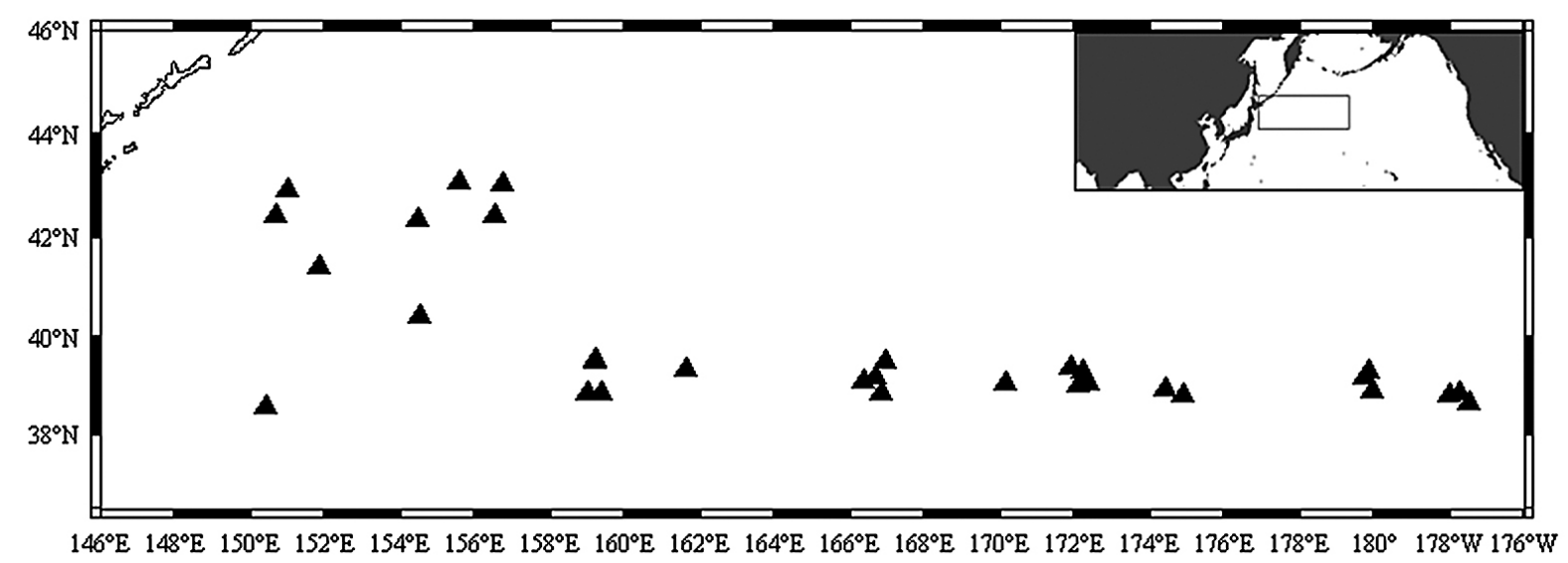

Fig. 1. - Distribution of sampling station of O. bartramii in North Pacific Ocean.

and growth pattern (Arkhipkin 2003, Ma et al. 2009, Chen et al. 2010). The beak also has specific characteristics and has been used in species identification (Clarke 1986, Ogden et al. 1998, Lu and Ickeringill 2002, Xavier and Cherel 2009). It has been proved that hard structures with a stable form can perform better than soft tissues (mantle, arm, tentacle, etc.) in squid population division (Martínez et al. 2002). Some new methods (landmarks and outline study) have also revealed that hard structures give good results in identity analysis (Dommergues 2000, Neige and Dommergues 2002, Lombarte et al. 2006, Neige 2006, Crespi-Abril et al. 2010). Some researchers may be cautious about using the beak as an identification material (Xavier et al. 2007), but it is still important for stock identification (Xavier et al. 2011). Therefore, the phenotypic characteristics, such as statoliths and beaks, can play a supportive role for stock identification and investigation.

A morphological variation of cephalopods has occurred among the species due to different genetic structures and populations, induced mainly by oceanographic environmental factors (Adkison 1995). Multivariate analyses of morphometric data have been used in some cephalopods at intraspecies (Martínez et al. 2002) and interspecies (Wolff 1984) levels for the evaluation of taxonomic and geographic variations. Stocks inhabiting different environments can impact their growth patterns, including the shapes of statolith and beak. It is common that the separation of stocks is only based on one material and then compared with the results obtained from different materials (Martínez et al. 2002), and the approach of integrating two materials in the stock separation is rarely used. In this study we integrated the morphological variables of statolith and beaks to compare their differences between stocks and between the sexes and to establish a discriminant function for two seasonal cohorts in the
North Pacific Ocean. Our aims were to identify different cohorts of $O$. bartramii by hard structures (statolith and beaks). This integrated approach can also be used for other species when different body structures are available in the stock identifications.

\section{MATERIALS AND METHODS}

The survey was carried out in the waters of $150^{\circ} \mathrm{E}$ $177^{\circ} \mathrm{W}$ and $38^{\circ}-44^{\circ} \mathrm{N}$ from May to October in 2010 to 2012 by the Chinese squid jigging vessel Jinhai 827 . The samples were collected randomly from the daily catches and frozen on board immediately for future analysis. The sampling station is shown in Figure 1.

A total of 570 individuals were collected. The mantle length (ML) was measured to the nearest $0.1 \mathrm{~mm}$ after thaw in the laboratory, and the sex was identified by their entirely different gonad structure. The sexual maturity stages were determined according to Lipinski and Underhill (1995). Statoliths and beaks were dissected according to Raya et al. (2010) and Chen et al. (2013). As a result, a subsample of 406 pairs of statoliths and beaks were prepared for the analysis. A pair of beaks were precisely paired with a pair of statoliths which had been picked from the same squid sample (Table 1).

Photos were taken using a charge-coupled device (CCD, connecting device) for right statolith under a $50 \times$ optical microscope (Olympus) and nine parameters of statolith morphology, i.e. total statolith length (TSL), maximum width (MW), dorsal dome length (DDL), lateral dome length (LDL), dorsal lateral length (DLL), rostrum lateral length (RLL), rostrum length (RL), rostrum width (RW) and wing length (WL), were measured by using the image analysis software WTTiger3000 (Fig. 2A). The parameters of each statolith

Table 1. - Sample information of $O$. bartramii for the two stocks.

\begin{tabular}{|c|c|c|c|c|c|c|}
\hline Stock structures & Sampling date & Latitude & Longitude & $\begin{array}{c}\text { Number of } \\
\text { samples }\end{array}$ & $\begin{array}{c}\text { Sex } \\
(\mathrm{F}, \mathrm{M}) \\
\end{array}$ & $\begin{array}{l}\mathrm{ML} \\
(\mathrm{mm})\end{array}$ \\
\hline \multirow[t]{3}{*}{ Northeast Pacific Stock } & 11-21 Jun. 2010 & $39^{\circ} 48^{\prime} \mathrm{N}-40^{\circ} 09^{\prime} \mathrm{N}$ & $171^{\circ} 52^{\prime} \mathrm{E}-175^{\circ} 29^{\prime} \mathrm{W}$ & 71 & 11,60 & $212-375$ \\
\hline & May. to Jun. 2011 & $38^{\circ} 42^{\prime} \mathrm{N}-39^{\circ} 20^{\prime} \mathrm{N}$ & $172^{\circ} 11^{\prime} \mathrm{E}-177^{\circ} 30^{\prime} \mathrm{W}$ & 23 & 21,2 & $226-411$ \\
\hline & May. to Jul. 2011 & $39^{\circ} 02^{\prime} \mathrm{N}-40^{\circ} 21^{\prime} \mathrm{N}$ & $174^{\circ} 52^{\prime} \mathrm{E}-179^{\circ} 58^{\prime} \mathrm{W}$ & 91 & 86,5 & $219-483$ \\
\hline \multirow{2}{*}{ Northwest Pacific Stock } & Jul. to Oct. 2011 & $38^{\circ} 42^{\prime} \mathrm{N}-39^{\circ} 20^{\prime} \mathrm{N}$ & $151^{\circ} 23^{\prime} \mathrm{E}-159^{\circ} 25^{\prime} \mathrm{E}$ & 173 & 100,73 & $173-452$ \\
\hline & Aug to Nov. 2011 & $40^{\circ} 58^{\prime} \mathrm{N}-43^{\circ} 21^{\prime} \mathrm{N}$ & $150^{\circ} 21^{\prime} \mathrm{E}-156^{\circ} 08^{\prime} \mathrm{E}$ & 47 & 34,13 & $208-363$ \\
\hline
\end{tabular}



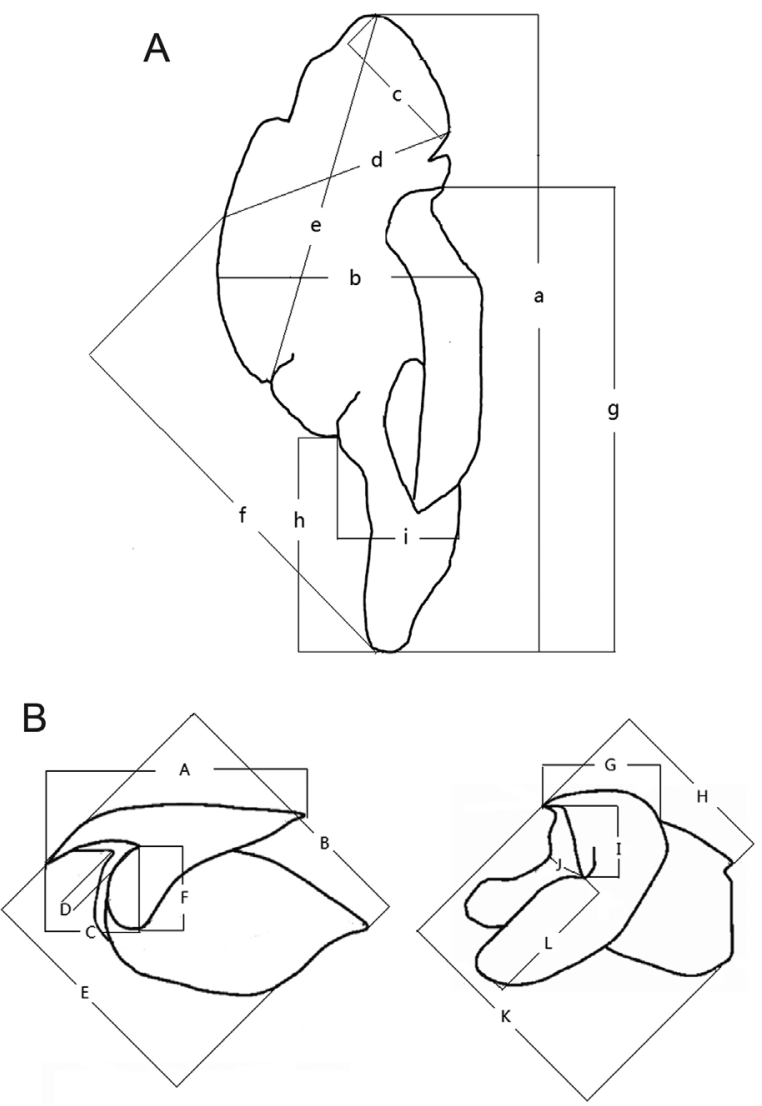

Fig. 2. - Schematic diagram of statolith (a) and beak (b) morphometric variables measured. Upper panel: a is total statolith length (TSL), $\mathrm{b}$ is maximum width (MW), $\mathrm{c}$ is dorsal dome length (DDL), $\mathrm{d}$ is lateral dome length (LDL), $\mathrm{e}$ is dorsal lateral length (DLL), $\mathrm{f}$ is rostrum lateral length (RLL), $g$ is rostrum length (RL), $h$ is rostrum width (RW), $i$ is wing length (WL). Lower panel: $A$ is upper hood length (UHL), B is upper crest length (UCL), C is upper rostrum length (URL), D is upper rostrum width (URW), $\mathrm{E}$ is upper lateral wall length (ULWL), F is upper wing length (UWL); $\mathrm{G}$ is lower hood length (LHL), H is lower crest length (LCL), $\mathrm{I}$ is lower rostrum length (LRL), $\mathrm{J}$ is lower rostrum width (LRW), $\mathrm{K}$ is lower lateral wall length (LLWL), $\mathrm{L}$ is lower wing length (LWL).

were measured to the nearest $0.01 \mu \mathrm{m}$. Beaks were also measured by vernier caliper, which included upper hood length (UHL), upper crest length (UCL), upper rostrum length (URL), upper rostrum width (URW), upper lateral wall length (ULWL), upper wing length (UWL), lower hood length (LHL), lower crest length (LCL), lower rostrum length (LRL), lower rostrum width (LRW), lower lateral wall length (LLWL), and lower wing length (LWL) (Fig. 2B). All the data for beaks were measured to the nearest $0.01 \mathrm{~mm}$. Measures of these variables were obtained independently by the two readers. The average was used if the range of the counts for the same sample was within 5\% of the error; otherwise it was measured again and the average of the variables of each reader was used for the same sample (Francis and Mattlin 1986, Chen et al. 2013).

A Student t-test was conducted to compare differences between the geographic stock and sexes. All of the variables were subjected to normal distribution (Kolmogorov-Smirnov test, P>0.05). Considering the impact of allometric growth (Moltschaniwskyj 1995, Lombarte et al. 1997, O'Dor and Hoar 2000), raw data standardization should be done before the analysis. The normalization method, as introduced by Lleonart (2000), was used to standardize morphological variables of statoliths and beaks. The accuracy of this method has been demonstrated in related investigations (Pineda et al. 2002, Vega et al. 2002, Lefkaditou and Bekas 2004, Chen et al. 2012). The TSL in statolith and UHL in beak were chosen as the independent variables to standardize the other variables of beaks (Chen et al. 2012). The standardized morphometric variables were represented by adding a lower case letter "s" after each variable, i.e. MWs, DDLs, LDLs, DLLs, RLLs, RLs, RWs, WLs; or UCLs, URLs, ULWLs, UWLs, LHLs, LCLs, LRLs, LLWLs and LWLs.

A stepwise discriminant analysis (SDA) was performed to select the significant standardized morphological variables based on the statolith, beak and the combination of the two structures $(\mathrm{P}<0.05$; Rencher 2002), and the classification functions were developed for the three different materials (i.e., statolith, beak, and their combinations). Finally, a leave-one-out crossvalidation (the Jackknife method) was used to determine rates of successful classification of squid from the two stocks for different uses of the hard structures.

\section{RESULTS}

\section{Sexual dimorphism and variation of different cohorts in hard structure sizes}

The morphometric variables of beaks and statoliths in both of the two cohorts are shown in Table 2 and

Table 2. - Beak morphological variables and $\mathrm{P}$ values (t-tests) of $O$. bartramii in the North Pacific Ocean; ***, $\mathrm{P}$ significant at $\alpha=0.05$; $\mathrm{ns}$, nonsignificant.

\begin{tabular}{|c|c|c|c|c|c|c|c|c|}
\hline \multirow[b]{2}{*}{ Variable } & \multicolumn{3}{|c|}{$\mathrm{NE}($ mean \pm std, mm) } & \multicolumn{3}{|c|}{ NW (mean \pm std, mm) } & \multirow{2}{*}{$\begin{array}{c}\mathrm{P} \text { (females } \\
\text { between } \\
\text { stocks) }\end{array}$} & \multirow{2}{*}{$\begin{array}{c}\mathrm{P} \text { (males } \\
\text { between } \\
\text { stocks) }\end{array}$} \\
\hline & Females & Males & $\begin{array}{l}\text { P (between } \\
\text { sexes) }\end{array}$ & Females & Males & $\begin{array}{l}\mathrm{P} \text { (between } \\
\text { sexes) }\end{array}$ & & \\
\hline UHL & $24.76 \pm 5.15$ & $17.16 \pm 0.86$ & $* * *$ & $19.01 \pm 4.05$ & $17.80 \pm 2.56$ & $* * *$ & $* * *$ & $* * *$ \\
\hline UCL & $30.42 \pm 6.24$ & $21.11 \pm 1.09$ & $* * *$ & $23.13 \pm 4.96$ & $21.45 \pm 3.22$ & $* * *$ & $* * *$ & $\mathrm{~ns}$ \\
\hline URL & $8.00 \pm 1.76$ & $5.87 \pm 1.55$ & $* * *$ & $6.27 \pm 1.35$ & $5.94 \pm 0.94$ & $* * *$ & $* * *$ & ns \\
\hline URW & $7.02 \pm 1.41$ & $4.78 \pm 0.48$ & $* * *$ & $5.14 \pm 1.22$ & $4.68 \pm 0.80$ & $* * *$ & $* * *$ & ns \\
\hline ULWL & $26.52 \pm 5.35$ & $18.15 \pm 1.43$ & $* * *$ & $20.02 \pm 4.29$ & $18.53 \pm 2.85$ & $* * *$ & $* * *$ & ns \\
\hline UWL & $8.23 \pm 1.70$ & $6.40 \pm 0.92$ & $* * *$ & $6.09 \pm 1.44$ & $5.99 \pm 0.99$ & ns & $* * *$ & $* * *$ \\
\hline LHL & $7.97 \pm 1.64$ & $5.91 \pm 0.50$ & $* * *$ & $6.33 \pm 1.30$ & $5.87 \pm 0.71$ & $* * *$ & $* * *$ & ns \\
\hline LCL & $15.43 \pm 3.37$ & $10.90 \pm 0.85$ & $* * *$ & $12.35 \pm 3.17$ & $10.99 \pm 1.84$ & $* * *$ & $* * *$ & ns \\
\hline LRL & $7.23 \pm 1.46$ & $5.34 \pm 0.85$ & $* * *$ & $5.46 \pm 1.28$ & $5.08 \pm 0.89$ & $* * *$ & $* * *$ & ns \\
\hline LRW & $7.31 \pm 1.50$ & $5.28 \pm 0.79$ & $* * *$ & $5.40 \pm 1.25$ & $5.00 \pm 0.71$ & $* * *$ & $* * *$ & $* * *$ \\
\hline LLWL & $22.83 \pm 4.59$ & $15.42 \pm 0.95$ & $* * *$ & $16.98 \pm 3.81$ & $15.54 \pm 2.74$ & $* * *$ & $* * *$ & ns \\
\hline LWL & $13.13 \pm 2.71$ & $9.15 \pm 0.66$ & $* * *$ & $9.84 \pm 2.33$ & $9.22 \pm 1.46$ & $* * *$ & $* * *$ & ns \\
\hline
\end{tabular}


Table 3. - Statolith morphological variables and P values (t-tests) of $O$. bartramii in the North Pacific Ocean.***, $\mathrm{P}$ significant at $\alpha=0.05 ; \mathrm{ns}$, nonsignificant

\begin{tabular}{|c|c|c|c|c|c|c|c|c|}
\hline \multirow[b]{2}{*}{ Variable } & \multicolumn{3}{|c|}{$\mathrm{NE}($ mean \pm std, $u \mathrm{~m})$} & \multicolumn{3}{|c|}{$\mathrm{NW}(\mathrm{mean} \pm \mathrm{std}, \mathrm{um})$} & \multirow{2}{*}{$\begin{array}{l}\mathrm{P} \text { (females } \\
\text { between } \\
\text { stocks) }\end{array}$} & \multirow{2}{*}{$\begin{array}{l}\mathrm{P} \text { (males } \\
\text { between } \\
\text { stocks) }\end{array}$} \\
\hline & Females & Males & $\begin{array}{l}\mathrm{P} \text { (between } \\
\text { sexes) }\end{array}$ & Females & Males & $\begin{array}{l}\text { P (between } \\
\text { sexes) }\end{array}$ & & \\
\hline TSL & $1446.44 \pm 126.76$ & $1272.02 \pm 58.51$ & $* * *$ & $1260.71 \pm 107.13$ & $1248.79 \pm 76.41$ & ns & $* * *$ & $* * *$ \\
\hline MW & $844.75 \pm 96.23$ & $745.62 \pm 39.20$ & $* * *$ & $724.92 \pm 82.89$ & $717.53 \pm 76.07$ & ns & $* * *$ & $* * *$ \\
\hline DDL & $601.04 \pm 94.41$ & $548.32 \pm 70.18$ & $* * *$ & $550.14 \pm 86.05$ & $540.142 \pm 92.63$ & ns & $* * *$ & ns \\
\hline DLL & $651.57 \pm 115.43$ & $515.99 \pm 72.88$ & $* * *$ & $575.90 \pm 117.82$ & $555.96 \pm 121.70$ & ns & $* * *$ & $* * *$ \\
\hline LDL & $866.25 \pm 105.53$ & $740.12 \pm 63.13$ & $* * *$ & $719.50 \pm 75.55$ & $711.53 \pm 65.48$ & ns & $* * *$ & $* * *$ \\
\hline RLL & $872.40 \pm 114.00$ & $774.33 \pm 73.05$ & $* * *$ & $802.65 \pm 109.54$ & $816.26 \pm 99.29$ & ns & $* * *$ & $* * *$ \\
\hline RL & $447.53 \pm 57.71$ & $386.66 \pm 41.72$ & $* * *$ & $418.36 \pm 53.86$ & $414.37 \pm 46.41$ & ns & $* * *$ & $* * *$ \\
\hline RW & $232.89 \pm 33.47$ & $212.50 \pm 27.05$ & $* * *$ & $187.87 \pm 34.19$ & $187.10 \pm 32.44$ & ns & $* * *$ & $* * *$ \\
\hline WL & $1123.73 \pm 112.01$ & $1017.86 \pm 59.64$ & $* * *$ & $1008.41 \pm 103.69$ & $1000.45 \pm 74.22$ & ns & $* * *$ & ns \\
\hline
\end{tabular}

Table 4. - The results estimated fromstepwise discriminant analysis of standardized beak variables for each sex of two populations, and a classification matrix with percentages of correctly classified individuals and cross-validation results.

\begin{tabular}{|c|c|c|c|c|c|c|}
\hline Step & Variable & F to enter & Wilks $\lambda$ & $d f 1$ & $d f 2$ & P value of Wilks $\lambda$ \\
\hline 1 & $\mathrm{URW}_{\mathrm{S}}$ & 108.583 & 0.551 & 3 & 400 & $<0.001$ \\
\hline 2 & $\mathrm{UWL}_{\mathrm{S}}$ & 51.138 & 0.522 & 6 & 798 & $<0.001$ \\
\hline 3 & $\mathrm{LCL}_{\mathrm{S}}$ & 39.256 & 0.469 & 9 & 969 & $<0.001$ \\
\hline 4 & ULWL $_{S}$ & 30.997 & 0.448 & 12 & 1051 & $<0.001$ \\
\hline 5 & $\mathrm{LRW}_{\mathrm{S}}$ & 25.828 & 0.433 & 15 & 1094 & $<0.001$ \\
\hline 6 & $\mathrm{URL}_{\mathrm{S}}$ & 22.366 & 0.419 & 18 & 1118 & $<0.001$ \\
\hline \multirow[t]{2}{*}{ Group } & \multicolumn{4}{|c|}{ Number of specimens classified } & \multirow[b]{2}{*}{ Original (\%) } & \multirow{2}{*}{$\begin{array}{c}\text { Cross-validation } \\
(\%)\end{array}$} \\
\hline & NW-M & NW-F & NE-M & NE-F & & \\
\hline NW-M & 33 & 29 & 20 & 4 & 38.4 & 36.0 \\
\hline NW-F & 32 & 59 & 21 & 21 & 44.4 & 43.6 \\
\hline NE-M & 8 & 12 & 47 & 0 & 70.1 & 68.7 \\
\hline NE-F & 6 & 10 & 14 & 88 & 74.6 & 74.6 \\
\hline Total & 86 & 133 & 67 & 118 & 56.9 & 55.7 \\
\hline
\end{tabular}

Table 3. Significant differences were found in the beak variables between sexes for the NE cohort $(\mathrm{P}<0.05)$. The NW cohort also shows significant differences for all variables $(\mathrm{P}<0.05)$ except for UWL $(\mathrm{P}>0.05)$. Apparently, sexual dimorphism of statolith variables is similar to that of the beak for the NE cohort, but t-tests showed no significant differences between males and females in the NW cohort $(\mathrm{P}>0.05)$. The above results indicated that between-sex differences were greater for the NE stock than for the NW stock (Tables 2 and 3).

For a given sex, different stocks also revealed different patterns with different hard structures. Female individuals had significant differences in beak morphology between stocks ( $\mathrm{t}$-test, $\mathrm{P}<0.01$ ), but had no significant differences in male squids ( $P>0.05)$, with the exception of UHL, UWL and LRW between stocks $(\mathrm{P}<0.05)$. The morphometric characteristics of statoliths showed significant difference between NE and NW cohorts in beak shape for female squids $(\mathrm{P}<0.05)$. DDL and WL showed no differences in male squids $(\mathrm{P}>0.05)$, but the other variables of statoliths were significantly different between stocks $(\mathrm{P}<0.05)$ (Table 3$)$.

\section{Discriminant analysis using standardized beak variables}

We divided the squid samples into four groups based on geography and sex. The beak was chosen as the only analytical material first. Stepwise discriminant analyses showed that the six variables, URW $\mathrm{UWL}_{\mathrm{S}}$, $\mathrm{LCL}_{\mathrm{S}}, \mathrm{ULWL}_{\mathrm{S}}, \mathrm{LRW}_{\mathrm{S}}$ and $\mathrm{URL}_{\mathrm{S}}$, could explain the morphological features among the four groups. The Wilks $\lambda$ was decreased from 0.551 to 0.419 (Table 4). Three canonical functions effectively separated these four groups, explaining $82.1 \%, 15.6 \%$ and $2.3 \%$ of the total variance. The distribution of the four groups on function 1 overlapped except for western females,
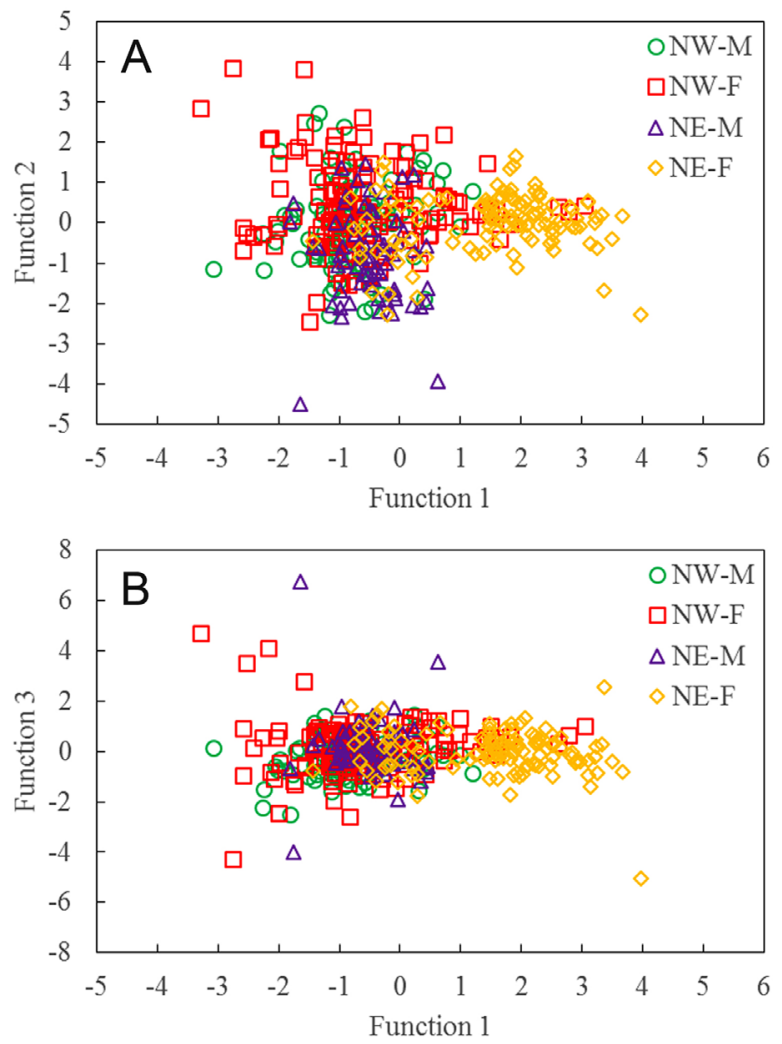

Fig. 3. - Canonical discriminant plots of standardized beak morphometric variables for samples in each sex from the two stocks in the North Pacific Ocean. 
Table 5. - Coefficients of parameters in classification functions using beaks as a material.

\begin{tabular}{|c|c|c|c|c|}
\hline \multirow{2}{*}{ Parameters } & \multicolumn{4}{|c|}{ Group } \\
\hline & NW-M & NW-F & NE-M & NE-F \\
\hline $\mathrm{URL}_{\mathrm{S}}$ & -8.442 & -9.151 & -12.161 & -13.027 \\
\hline $\mathrm{URW}_{\mathrm{S}}$ & -62.884 & -61.306 & -59.247 & -53.328 \\
\hline $\mathrm{ULWL}_{\mathrm{S}}$ & 217.729 & 216.815 & 209.660 & 220.197 \\
\hline $\mathrm{UWL}_{\mathrm{S}}$ & -16.961 & -20.450 & -12.756 & -17.187 \\
\hline $\mathrm{LCL}_{\mathrm{S}}{ }^{\mathrm{s}}$ & -21.760 & -17.860 & -22.924 & -28.883 \\
\hline $\mathrm{LRW}_{\mathrm{S}}$ & -72.472 & -72.042 & -66.745 & -66.229 \\
\hline Constant & -207.284 & -211.796 & -198.656 & -232.122 \\
\hline
\end{tabular}

which could be more easily identified (Fig. 3). The cross-validation rate was $36.0 \%$ for the western males (NW-M), $43.6 \%$ for the western females (NW-F), $68.7 \%$ for the eastern males (NE-M) and $74.6 \%$ for the eastern females (NE-F), showing slightly lower values than the original ones (Table 4). The classification functions with coefficients are presented in Table 5.

\section{Discriminant analysis using standardized statolith variables}

When referring to statoliths, $\mathrm{RL}_{S}, \mathrm{LDL}_{\mathrm{S}}, \mathrm{RLL}_{\mathrm{S}}$, $\mathrm{RW}_{\mathrm{S}}$ and $\mathrm{WL}_{\mathrm{S}}$ were chosen as the most important variables from ten morphological parameters for the population discrimination (Table 6). The total Wilks $\lambda$ was 2.626 for the five variables. Canonical functions 1 and 2, explaining $80.9 \%$ and $18.5 \%$, respectively, together explained almost $100 \%$ of all the groups $(99.4 \%)$. The distribution of the NE-M revealed little overlap with the other three groups on function 1 (Fig. 4). Therefore, the highest cross-validation rate was $86.6 \%$ for the $\mathrm{NE}-\mathrm{M}$, and the remainder was $36.0 \%$ for the NW-M, $37.6 \%$ for the NW-F and $50.8 \%$ for the NE-F. The classification result was similar to that of the beak (Table $6)$. The classification functions with coefficients are presented in Table 7.

\section{Discriminant analysis with combination of standardized beak and statolith variables}

When combined with the two hard structures, the SDA results showed that eight variables $\left(\mathrm{URW}_{\mathrm{S}}, \mathrm{MW}_{\mathrm{S}}\right.$, $\mathrm{RLL}_{S}, \mathrm{UWL}_{\mathrm{S}}, \mathrm{LLWL}_{\mathrm{S}}, \mathrm{DLL}_{\mathrm{S}}, \mathrm{LCL}_{\mathrm{S}}$ and $\mathrm{RL}_{\mathrm{S}}$ ) were identified effectively among all the four groups within geography and sex. Total Wilks $\lambda$ was 1.630 , decreasing sharply from 0.551 to 0.127 (Table 8 ). Canonical func-
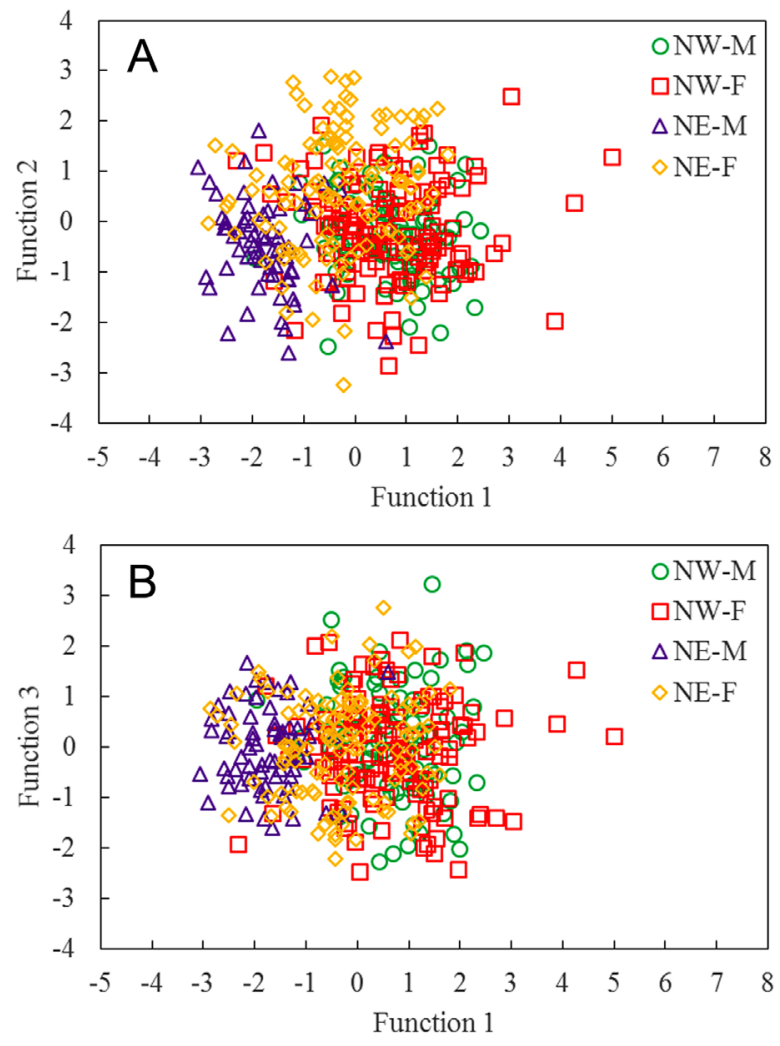

Fig. 4. - Canonical discriminant plots of standardized statolith morphological variables of samples in each sex from the two stocks in the North Pacific Ocean.

Table 7. - Coefficients of parameters in classification functions using statoliths as a material.

\begin{tabular}{lcccc}
\hline \multirow{2}{*}{ Parameters } & NW-M & NW-F & NE-M & NE-F \\
& 53.722 & 55.337 & 55.841 & 63.644 \\
LDL $_{S}$ & 118.483 & 116.221 & 111.051 & 110.942 \\
RLL $_{S}$ & 372.294 & 372.568 & 367.833 & 365.621 \\
WL $_{S}$ & 114.364 & 115.273 & 105.825 & 112.025 \\
RL $_{S}$ & 36.761 & 36.775 & 39.616 & 40.201 \\
RW $_{S}$ & -4572.500 & -4579.031 & -4371.268 & -4524.986 \\
Constant & & & & \\
\hline
\end{tabular}

tion 1 showed the highest rate of $86.5 \%$, followed by $12.3 \%$ and $1.2 \%$ for canonical functions 2 and 3 , respectively (Table 8). The different geographical stocks were effectively separated by function 1 , and there was little overlap between sexes in the NW stock (Fig. 5). Overall,

Table 6. - The results estimated from stepwise discriminant analysis of standardized statolith variables for each sex of two populations, and a classification matrix with percentages of correctly classified individuals and cross-validation results.

\begin{tabular}{|c|c|c|c|c|c|c|}
\hline Step & Variable & $\mathrm{F}$ to enter & Wilks $\lambda$ & $d f 1$ & $d f 2$ & $\mathrm{P}$ value of Wilks $\lambda$ \\
\hline 1 & $\mathrm{RL}_{\mathrm{S}}$ & 87.087 & 0.605 & 3 & 400 & $<0.001$ \\
\hline 2 & $\mathrm{LDL}_{\mathrm{S}}$ & 45.585 & 0.555 & 6 & 798 & $<0.001$ \\
\hline 3 & $\operatorname{RLL}_{S}^{\prime}$ & 34.740 & 0.506 & 9 & 969 & $<0.001$ \\
\hline 4 & $\mathrm{RW}_{\mathrm{S}}^{\mathrm{s}}$ & 27.079 & 0.490 & 12 & 1051 & $<0.001$ \\
\hline 5 & $\mathrm{WL}_{\mathrm{S}}^{\mathrm{s}}$ & 22.910 & 0.470 & 15 & 1094 & $<0.001$ \\
\hline \multirow[t]{2}{*}{ Group } & \multicolumn{4}{|c|}{ Number of specimens classified } & Original (\%) & Cross-validation \\
\hline & NW-M & NW-F & NE-M & NE-F & & $(\%)$ \\
\hline NW-M & 35 & 31 & 3 & 17 & 40.7 & 36.0 \\
\hline NW-F & 42 & 55 & 7 & 29 & 41.4 & 37.6 \\
\hline NE-M & 2 & 0 & 58 & 7 & 86.6 & 86.6 \\
\hline NE-F & 13 & 18 & 26 & 61 & 51.7 & 50.8 \\
\hline Total & 86 & 133 & 67 & 118 & 55.1 & 52.8 \\
\hline
\end{tabular}


Table 8. - The results estimated from stepwise discriminant analysis of combined standardized statolith and beak variables for each sex of two populations, and a classification matrix with percentages of correctly classified individuals and cross-validation results.

\begin{tabular}{|c|c|c|c|c|c|c|}
\hline Step & Variable & $\mathrm{F}$ to enter & Wilks $\lambda$ & $d f 1$ & $d f 2$ & $\mathrm{P}$ value of Wilks $\lambda$ \\
\hline 1 & $\mathrm{URW}_{\mathrm{S}}$ & 108.583 & 0.551 & 3 & 400 & $<0.001$ \\
\hline 2 & $\mathrm{MW}_{\mathrm{S}}^{\mathrm{s}}$ & 158.336 & 0.208 & 6 & 798 & $<0.001$ \\
\hline 3 & $\mathrm{RLL}_{\mathrm{S}}$ & 114.037 & 0.172 & 9 & 969 & $<0.001$ \\
\hline 4 & $\mathrm{UWL}_{\mathrm{S}}$ & 88.776 & 0.157 & 12 & 1051 & $<0.001$ \\
\hline 5 & LLWL $_{S}$ & 73.143 & 0.147 & 15 & 1094 & $<0.001$ \\
\hline 6 & $\mathrm{LDL}_{\mathrm{S}}$ & 63.396 & 0.137 & 18 & 1118 & $<0.001$ \\
\hline 7 & $\mathrm{LCL}_{\mathrm{S}}$ & 55.599 & 0.131 & 21 & 1132 & $<0.001$ \\
\hline 8 & $\mathrm{RL}_{\mathrm{S}}$ & 49.309 & 0.127 & 24 & 1140 & $<0.001$ \\
\hline \multirow[b]{2}{*}{ Group } & \multicolumn{4}{|c|}{ Number of specimens classified } & \multirow[b]{2}{*}{ Original (\%) } & \multirow{2}{*}{$\begin{array}{c}\text { Cross-validation } \\
(\%)\end{array}$} \\
\hline & NW-M & NW-F & NE-M & $\mathrm{NE}-\mathrm{F}$ & & \\
\hline NW-M & 50 & 33 & 3 & 0 & 58.1 & 53.5 \\
\hline NW-F & 46 & 78 & 7 & 2 & 58.6 & 56.4 \\
\hline NE-M & 0 & 1 & 65 & 1 & 97.0 & 95.5 \\
\hline NE-F & 0 & 1 & 21 & 96 & 81.4 & 81.4 \\
\hline Total & 86 & 133 & 67 & 118 & 73.8 & 71.7 \\
\hline
\end{tabular}
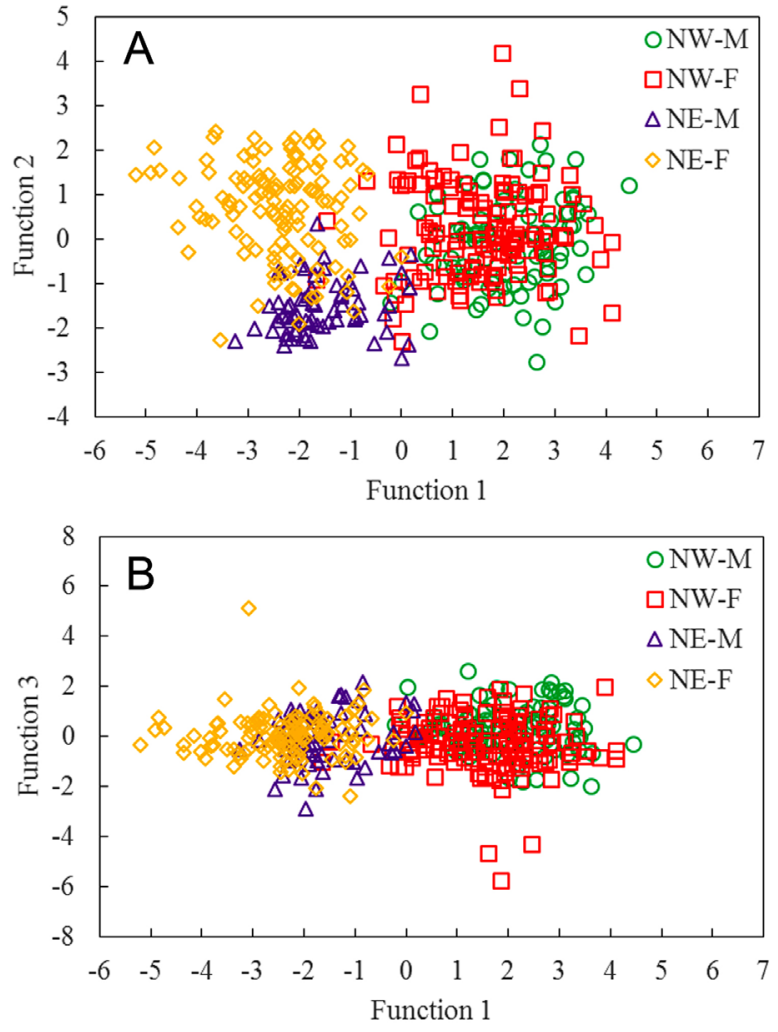

Fig. 5. - Canonical discriminant plots of combined with standardized statolith and beak morphometric variables of samples in each sex from the two stocks in the North Pacific Ocean.

the successful classification rate was $71.7 \%$ with $53.5 \%$ for the NW-M, with the remainder for the NW-F at $56.4 \%, 95.5 \%$ for the NE-M and $81.4 \%$ for the NE-F respectively, over $15 \%$ higher than in the classification with either hard structure alone. The classification functions with coefficients are presented in Table 9.

\section{DISCUSSION}

Since the 1960s, the structures and morphological characteristics of the statolith and beak of cephalopods have attracted much interest (Clarke 1962, 1978, 2003, Villanueva 1992, Arkhipkin 2003, Chen et al. 2012).
Table 9. - Coefficients of parameters in classification functions using beaks and statoliths as materials.

\begin{tabular}{lcccc}
\hline \multirow{2}{*}{ Parameters } & \multirow{4}{c}{ NW-M } & NW-F & NE-M & NE-F \\
\hline MW $_{S}$ & 1250.352 & 1246.126 & 1227.866 & 1218.402 \\
DLL $_{S}$ & 150.988 & 150.077 & 143.442 & 144.485 \\
RLL $_{S}$ & 508.075 & 505.310 & 492.537 & 493.931 \\
RL $_{S}$ & -3.536 & -2.393 & -7.247 & -1.873 \\
URW $_{S}$ & -169.509 & -168.181 & -164.857 & -159.222 \\
UWL $_{S}$ & 28.458 & 24.553 & 29.583 & 26.374 \\
LCL $_{S}$ & -216.664 & -212.422 & -212.382 & -219.119 \\
LLWL $_{S}$ & -282.051 & -280.431 & -274.622 & -263.275 \\
Constant & -10956.687 & -10885.578 & -10404.056 & -10417.180 \\
\hline
\end{tabular}

For this reason we chose the statolith and beak as materials in this study for their rigid characteristics and wide usage. Meanwhile, data standardization can effectively remove the influence of allometric growth. There are also other sorts of data standardization, such as logtransformation. Some studies have already proved that the method of data standardization used in this study is more effective than the original data, and there are other methods for identification with a low rate of misclassification (Chen et al. 2012, Fang et al. 2012)

Sexual dimorphism usually occurs in cephalopods (Mercer et al. 1980, Pineda et al. 2002, Vega et al. 2002, Chen et al. 2012). Our study also found this difference in the NE stock in both the statolith and beak $(\mathrm{P}<0.05)$, and this was mainly affected by the sex-segregated migration whereby males are separated from northward migrating females, which stay at the spawning/nursery ground to avoid cannibalism (Yatsu et al. 1997, O'Dor and Dawe 1998, Ichii et al. 2009). This meant that we could not find more male individuals in our study areas. With the disparity of latitude distribution, environmental conditions can eventually affect the morphology of hard structures. This was also reflected in the results from the discriminant analysis (Tables 2 and 3 ).

The NW stock revealed a different situation in morphometric characteristics. Most beak characteristics varied according to sex $(\mathrm{P}<0.05)$; however, none of the statolith variables showed differences between the sexes $(\mathrm{P}>0.05)$. Both sexes of the NW stock had lived in the same area, and shared a similar oceanographic environment with a single migration pattern. Therefore, the difference in the beaks might have been 
caused by asynchronous maturation, which is a type of reproductive strategy commonly found in other cephalopods (Rocha et al. 2001). However, this sexual dimorphism was small, as is shown by the overlapped dots in the discriminant analysis (Figs 3 and 4).

The population structure of $O$. bartramii in the $\mathrm{Pa}$ cific Ocean has been discussed in previous studies (Murakami et al. 1981, Murata 1990, Bower and Margolis 1991), and the two main seasonal cohorts (the NE stock with large size located east of $170^{\circ} \mathrm{E}$ and the NW stock with small size located west of $170^{\circ} \mathrm{E}$, Chen and Chiu 2003) lived in different habitats. One of the reasons for the difference in statolith (both sexes) and beak (female) morphology is a separated migration trajectory. The NW stock occurs in the subtropical frontal zone (STFZ) with rich productivity, whereas NE stock occurs in the subtropical domain which is less productive because it is far from the transition zone chlorophyll front (TZCF). When the TZCF shifts northward in spring, the migration pattern of the NW stock moves with the change of the TZCF, but the NE stock remains southward to the north of the TZCF until summer or autumn (Ichii et al. 2009). Therefore, the NW stock is of large size in the enhanced productivity water, feeding on myctophid (Symbolophorus californiensis, Ceratoscopelus warmingi) and squid (Onychoteuthis borealijaponica, Gonatus berryi). The small-sized NE stock feed on euphausiids, amphipods and fish (Maurolicus imperatorius) (Ichii et al. 2004). This disparity of feeding may induce variation in the beak morphology (Uchikawa et al. 2009). The high rate of classification also demonstrated the difference between the two stocks (Fig. 5).

Many studies have focused on interspecies identification, with relatively high classification rates using beaks (Martínez et al. 2002, Pineda et al. 2002, Chen et al. 2012). The total correct classification rate was nearly $50 \%$ for both statoliths and beaks, but increased to about $70 \%$ for the combination of both hard parts. Thus, adding more relevant variables can increase the success of classification, using SDA to improve the accuracy of classification by retaining some highly correlated variables although the results of correct classification are still low compared with other studies of cephalopods (Martínez et al. 2002, Chen et al. 2012). The result was credible as the first three variables entered the combination group, which all entered the beak-based and statolith-based SDA (Table 8).

There are still two sub-stocks in the northwest Pacific (central stock and east stock) and northeast Pacific (west stock and central-east stock) (Bower and Ichii 2005). The relatively high successful classification rates demonstrate that morphology of hard parts in sub-stocks showed less variation and it is hard to separate them using only morphology of hard structures.

In conclusion, hard structures, such as statolith and beak in cephalopod, are credible materials to identify at an intraspecies level. The NE stock of $O$. bartramii showed sexual dimorphism in hard parts, but the NW stock showed no significant difference by sex. The among-stock differences were greater in the female group than in the male group. The classification approach could separate the two stocks, especially the
NE stock, with more than $80 \%$ accuracy. Meanwhile, data standardization and variable combination could help improve the accuracy of the classification. As the overlapped dots showed in the results, we must be cautious of over-interpretation of phenotype-based analysis, which is more reliable when combined with genetic methods.

\section{ACKNOWLEDGEMENTS}

This work was funded by the National Science Foundation of China (NSFC41306127 and NSFC41276156), the National Science Foundation of Shanghai (13ZR1419700), the Innovation Programme of Shanghai Municipal Education Commission (13YZ091), the State 863 projects (2012AA092303), the Funding Program for Outstanding Dissertations in Shanghai Ocean University, the Funding Scheme for Training Young Teachers in Shanghai Colleges and the Shanghai Leading Academic Discipline Project (Fisheries Discipline). Y Chen's involvement was supported by SHOU International Center for Marine Studies and Shanghai 1000 Talent Program.

\section{REFERENCES}

Adkison M.D. 1995. Population differentiation in Pacific salmons: local adaptation genetic drift, or the environment? Can. J. Fish. Aquat. Sci. 52(12): 2762-2777.

http://dx.doi.org/10.1139/f95-865

Arkhipkin A.I. 2003. Towards identification of the ecological lifestyle in nektonic squid using statolith morphometry. J. Mollus. Stud. 69: 171-178.

http://dx.doi.org/10.1093/mollus/69.3.171

Arkhipkin A.I. 2005. Statolith as black boxes (life recorders) in squid. Mar. Freshwater Res. 56(5): 573-583. http://dx.doi.org/10.1071/MF04158

Arkhipkin A.I., Bizikov V.A. 2000. Role of the statolith in functioning of the acceleration receptor system in squids and sepioids. J. Zool. 250(1): 31-55. http://dx.doi.org/10.1111/j.1469-7998.2000.tb00575.x

Arkhipkin A.I., Shcherbich Z.N. 2012. Thirty years' progress in age determination of squid using statoliths. J. Mar. Biol. Ass. U. K. 92(06): 1389-1398. http://dx.doi.org/10.1017/S0025315411001585

Bizikov V. A., Arkhipkin A. I. 1997. Morphology and microstructure of the gladius and statolith from the boreal Pacific giant squid Moroteuthis robusta (Oegopsida; Onychoteuthidae). J. Zool. 241(3): 475-492. http://dx.doi.org/10.1111/j.1469-7998.1997.tb04839.x

Bower J.R., Ichii T. 2005. The red flying squid (Ommastrephes bartramii): A review of recent research and the fishery in Japan. Fish. Res. 76(1): 39-55. http://dx.doi.org/10.1016/j.fishres.2005.05.009

Bower S.M., Margolis L. 1991. Potential use of helminth parasites in stock identification of flying squid, Ommastrephes bartramii, in North Pacific waters. Can. J. Zool. 69(4): 1124-1126. http://dx.doi.org/10.1139/z91-158

Burke W.T., Freeberg M., Miles E.L. 1993. United Nations Resolutions on driftnet fishing: An unsustainable precedent for high seas and coastal fisheries management. Ocean Dev. Int. Law. 25: $127-186$. http://dx.doi.org/10.1080/00908329409546030

Cabanellas-Reboredo M., Alós J., Palmer M., et al. 2011. Simulating the indirect handline jigging effects on the European squid (Loligo vulgaris) in captivity. Fish. Res. 110(3): 435-440. http://dx.doi.org/10.1016/j.fishres.2011.05.013

Cadrin S.X., Silva V.M. 2005. Morphometric variation of yellowtail flounder. ICES J. Mar. Sci. 62: 683-694. http://dx.doi.org/10.1016/j.icesims.2005.02.006

Castanhari G., Tomás A.R.G. 2012. Beak increment counts as a tool for growth studies of the common octopus Octopus vulgaris in southern Brazil. Bol. Inst. Pesca, São Paulo 38(4): 323-331. 
Chen C.S. 2010. Abundance trends of two neon flying squid (Ommastrephes bartramii) stocks in the North Pacific. ICES J. Mar. Sci. 67(7): 1336-1345.

Chen C.S., Chiu T.S. 2003. Variations of life history parameters in two geographical groups of the neon flying squid, Ommastrephes bartramii, from the North Pacific. Fish. Res. 63: 349-366. http://dx.doi.org/10.1016/S0165-7836(03)00101-2

Chen X.J., Tian S.Q., Ye X.C. 2002. Study on population structure of flying squid in Northwestern Pacific based on gray system theory. J. Shanghai Fish. Univ. 11(4): 335-341. (In Chinese with English Abstract)

Chen X.J., Liu B.L., Wang Y.G. 2009. Cephalopod of the world. Marine Press, Beijing, China, 1064 pp.

Chen X.J., Ma J., Liu B.L., et al. 2010. Effects of sexual maturity and body size on statolith shape of Ommastrephes bartramii in the Northwest Pacific Ocean. J. Fish. China. 30(6): 928-934. (In Chinese with English abstract)

Chen F., Chen X.J., Lu H.J., et al. 2011. Comparison of biological characteristics of Ommastrephes bartarmii between two different areas in the east central waters of North Pacific Ocean. J. Shanghai Fish. Univ. 20(5): 759-764. (In Chinese with English Abstract)

Chen X.J., Lu H.J., Liu B.L., et al. 2012. Species identification of Ommastrephes bartramii, Dosidicus gigas, Sthenoteuthis oualaniensis and Illex argentinus (Ommastrephidae) using beak morphological variables. Sci. Mar. 76(3): 473-481. http://dx.doi.org/10.3989/scimar.03408.05B

Chen X.J., Li J.H., Liu B.L., et al. 2013. Age, growth and population structure of Jumbo flying squid, Dosidicus gigas, off the Costa Rica Dome. J. Mar. Biol. Ass. U. K. 93:567-573 http://dx.doi.org/10.1017/S0025315412000422

Cherel Y., Hobson K.A. 2005. Stable isotopes, beaks and predators: a new tool to study the trophic ecology of cephalopods, including giant and colossal squids. Proc. R. Soc. Lond. B. 272: 1601-1607. http://dx.doi.org/10.1098/rspb.2005.3115

Cherel Y., Ridoux V., Spitz J., et al. 2009. Stable isotopes document the trophic structure of a deep-sea cephalopod assemblage including giant octopod and giant squid. Biol. Lett. 5: 364-367. http://dx.doi.org/10.1098/rsbl.2009.0024

Clarke M.R. 1962. The identification of cephalopod "beaks" and the relationship between beak size and total body weight. Bull. Br. Mus. nat. Hist. Zool. 8: 419-480

Clarke M.R. 1978. The cephalopod statolith-introduction to its form. J. Mar. Biol. Ass. U.K. 58: 701-712. http://dx.doi.org/10.1017/S0025315400041345

Clarke M.R. 1986. A handbook for the identification of cephalopod beaks. Clarendon Press, Oxford, UK, 273 pp.

Clarke M.R. 2003. Potential of statoliths for interpreting coleoid evolution: a brief review. Ber. Palä. Abh. 3: 37-47.

Crespi-Abril A.C., Morsan E.M., Barón P.J. 2010. Analysis of the ontogenetic variation in body and beak shape of the Illex argentinus inner shelf spawning groups by geometric morphometrics. J. Mar. Biol. Ass. U. K. 90(03): 547-553. http://dx.doi.org/10.1017/S0025315409990567

Dommergues J.L., Neige P., Boletzky S.V. 2000. Exploration of morphospace using procrustes analysis in statoliths of cuttlefish and squid (Cephalopoda: Decabrachia)-evolutionary aspects of form disparity. Veliger-berkeley, 43(3): 265-276.

Durholtz M.D., Lipinski M.R., Przybylowicz W.J., et al. 1997. Nuclear microprobe mapping of statoliths of chokka squid Loligo vulgaris reynaudii d'Orbigny, 1845. Biol. Bull. 193(2): 125-140. http://dx.doi.org/10.2307/1542758

Fang Z., Chen X.J., Lu H.J., et al. 2012. Morphological differences in statolith and beak between two spawning stocks for Illex argentinus. Acta. Ecol. Sin. 32(19): 5986-5997. (In Chinese with English Abstract) http://dx.doi.org/10.5846/stxb201109101331

Francis R.I.C.C., Mattlin R.H. 1986. A possible pitfall in the morphometric application of discriminant analysis: measurement bias. Mar. Biol. 93(2): 311-313. http://dx.doi.org/10.1007/BF00508269

Guerra A., Rodríguez-navarro A.B., González A.F., et al. 2010. Life-history traits of the giant squid Architeuthis dux revealed from stable isotope signatures recorded in beaks. ICES J. Mar. Sci. 67(7): 1425-1431.

Hanlon R.T., Messenger J.B. 1996. Cephalopod Behaviour. Cambridge University Press Cambridge, UK, 232 pp.

Ichii T., Mahapatra K., Sakai M., et al. 2004. Differing body size between the autumn and the winter-spring cohorts of neon flying squid (Ommastrephes bartramii) related to the oceanographic regime in the North Pacific: a hypothesis. Fish. Oceanogr. 13: 295-309 http://dx.doi.org/10.1111/j.1365-2419.2004.00293.x

Ichii T., Mahapatra K., Sakai M., et al. 2009. Life history of the neon flying squid: effect of the oceanographic regime in the North Pacific Ocean. Mar. Ecol. Prog. Ser. 378: 1-11. http://dx.doi.org/10.3354/meps07873

Ikeda Y., Arai N., Sakamoto W., et al. 1996. PIXE analysis of trace elements in squid statoliths: comparison between Ommastrephidae and Loliginidae. International Journal of PIXE. 6: 537-542. http://dx.doi.org/10.1142/S0129083596000594

Ikeda Y., Arai N., Sakamoto W., et al. 1997. Comparison on trace elements in squid statoliths of different species' origin as available key for taxonomic and phylogenetic study. International Journal of PIXE. 7: 141-146. http://dx.doi.org/10.1142/S0129083597000175

Ikeda Y., Arai N., Kidokoro H., et al. 2003. Strontium: calcium ratios in statoliths of Japanese common squid Todarodes pacificus (Cephalopoda: Ommastrephidae) as indicators of migratory behavior. Mar. Ecol. Prog. Ser. 251(1): 169-179. http://dx.doi.org/10.3354/meps251169

Jackson G.D., Domeier M.L. 2003. The effects of an extraordinary $\mathrm{El} \mathrm{Ni-o/La} \mathrm{Ni-a} \mathrm{event} \mathrm{on} \mathrm{the} \mathrm{size} \mathrm{and} \mathrm{growth} \mathrm{of} \mathrm{the} \mathrm{squid} \mathrm{Loligo}$ opalescens off Southern California. Mar. Biol. 142(5): 925-935.

Katugin O.N. 2002. Patterns of genetic variability and population structure in the North Pacific squids Ommastrephes bartramii, Todarodes pacificus and Berryteuthis magister. Bull. Mar. Sci. 71(1): 383-420.

Kurosaka K., Yamashita H., Ogawa M., et al. 2012. Tentacle-breakage mechanism for the neon flying squid (Ommastrephes bartramii) during the jigging capture process. Fish. Res. 121: 9-16. http://dx.doi.org/10.1016/j.fishres.2011.12.016

Lefkaditou E., Bekas P. 2004. Analysis of beak morphometry for the horned octopus Eledone cirrhosa (Cephalopoda: Octopoda) from the Thracian Sea (NE Mediterranean). Mediterr. Mar. Sci. 5(1): 143-149. http://dx.doi.org/10.12681/mms.219

Lefkaditou E., Peristeraki P., Chartosia N., et al. 2011. Recent findings of Ommastrephes bartramii (Cephalopoda: Ommastrephidae) in the eastern Mediterranean and the implication on its range expansion. Mediterr. Mar. Sci. 12(2): 413-428. http://dx.doi.org/10.12681/mms.41

Lipinski M. R., Underhill L. G. 1995. Sexual maturation in squid: quantum or continuum. S. Afr. J. Mar. Sci. 15: 207-223 http://dx.doi.org/10.2989/02577619509504844

Lleonart J., Salat J., Torres G.J. 2000. Removing allometric effects of body size in morphological analysis. J. Thero. Biol. 205: 85-93. http://dx.doi.org/10.1006/jtbi.2000.2043

Lombarte A., Sanchez P., Morales-Nin B. 1997. Intraspecific shape variability in statoliths of three cephalopod species. Vie Milieu 47: 165-169.

Lombarte A., Rufino M.M., Sánchez P. 2006. Statolith identification of Mediterranean Octopodidae, Sepiidae, Loliginidae, Ommastrephidae and Enoploteuthidae based on warp analyses. J. Mar. Biol. Ass. U. K. 86(04): 767-771. http://dx.doi.org/10.1017/S0025315406013683

Lu C.C., Ickeringill R. 2002. Cephalopod beak identification and biomass estimation techniques: tools for dietary studies of southern Australian finfishes. Mus. Victoria Sci. Rep. 6: 1-65.

Ma J., Chen X.J., Liu B.L., et al. 2009. Morphologic Features of Statolith for Ommastrephes bartramii in the Northwest Pacific Ocean. Periodical of Ocean University of China 39(2): 215-220. (In Chinese with English abstract)

Martínez P., Sanjuan A., Guerra A. 2002. Identification of Illex coindetii, I. illecebrosus and I. argentines (Cephalopoda: Ommastrephidae) throughout the Atlantic Ocean by body and beak characters. Mar. Biol. 141:131-143 http://dx.doi.org/10.1007/s00227-002-0796-7

Mercer M.C., Misra R.K., Hurley G.V. 1980. Sex determination of the Ommastrephid squid Illex illecebrosus using beak morphometric. Can. J. Fish. Aquat. Sci. 37: 283-286 http://dx.doi.org/10.1139/f80-035

Miserez A., Rubin D., Waite J.H. 2010. Cross-linking Chemistry of Squid Beak. J. Biol. Chem. 285(49): 38115-38124 http://dx.doi.org/10.1074/jbc.M110.161174

Moltschaniwskyj N.A. 1995. Changes in shape associated with growth in the loliginid squid Photololigo sp.: a morphometric approach. Can. J. Zool. 73(7): 1335-1343. http://dx.doi.org/10.1139/z95-157 
Murakami K., Watanabe Y., Nakata J. 1981. Growth, distribution and migration of flying squid (Ommastrephes bartrami) in the North Pacific. In: Mishima, S. (ed.), Pelagic animals and environments around the Subarctic Boundary in North Pacific. Hokkaido University, Research Institute of North Pacific Fisheries, Hakodate, pp. 161-179 (In Japanese with English abstract)

Murata M. 1990. Oceanic resources of squids. Mar. Behav. Phys. 18: $19-71$ http://dx.doi.org/10.1080/10236249009378779

Murata M., Hayase S. 1993. Life history and biological information on flying squid (Ommastrephes bartramii) in the North Pacific Ocean. Bull. Int. Nat. North Pacific Comm. 53: 147-182.

Nagasawa K., Mori J., Okamura H. 1998. Parasites as biological tags of stocks of neon flying squid (Ommastrephes bartramii) in the North Pacific Ocean, In: Okutani, T. (1998), Contributed papers to International Symposium on Large Pelagic Squids, July 18-19, 1996, for JAMARC's 25th anniversary of its foundation, pp. 49-64.

Neige P. 2006. Morphometrics of hard structures in cuttlefish. Vie Milieu 56(2): 121-127

Neige P., Dommergues, J.L. 2002. Disparity of beaks and statoliths of some coleoids a morphometric approach to depict shape differentiation. Gabh. der Geol. Bun. 57: 393-399

O’Dor R.K., Dawe E.G. 1998. Illex illecebrosus. In: Rodhouse P.G., Dawe E.G., O’Dor R.K. (eds), Squid recruitment dynamics. FAO Fish Tech Pap 376, Rome, pp. 77-104.

O'Dor R.K., Hoar J.A. 2000. Does geometry limit squid growth? ICES J. Mar. Sci. 57(1): 8-14. http://dx.doi.org/10.1006/jmsc.1999.0502

Ogden R.S., Allcock A.L., Wats P.C., et al. 1998. The role of beak shape in octopodid taxonomy. S. Afr. J. Mar. Sci. 20(1): 29-36. http://dx.doi.org/10.2989/025776198784126476

Perales-Raya C., Jurado-Ruzafa A., Bartolomé A., et al. 2014. Age of spent Octopus vulgaris and stress mark analysis using beaks of wild individuals. Hydrobiologia 725(1): 105-114. http://dx.doi.org/10.1007/s10750-013-1602-x

Piatkowski U., Pütz K., Heinemann H. 2001. Cephalopod prey of king penguins (Aptenodytes patagonicus) breeding at Volunteer Beach, Falkland Islands, during austral winter 1996. Fish. Res. 52(1): 79-90. http://dx.doi.org/10.1016/S0165-7836(01)00232-6

Pierce G. J., Hastie L. C., Guerra A., et al. 1994. Morphometric variation in Loligo forbesi and Loligo vulgaris: regional, seasonal, sex, maturity and worker differences. Fish. Res. 21(1): 127-148. http://dx.doi.org/10.1016/0165-7836(94)90100-7

Pineda S.E., Hernández D.R., Brunetti N.E, et al. 2002. Morphological identification of two Southwest Atlantic Loliginid squids: Loligo gahi and Loligo sanpaulensis. Rev. Invest. Desarr. Pesq. 15: 67-84.

Raya C.P., Hernández-González C.L. 1998. Growth lines within the beak microstructure of the octopus Octopus vulgaris Cuvier, 1797. S. Afr. J. Mar. Sci. 20(1): 135-142 http://dx.doi.org/10.2989/025776198784126368

Raya C.P., Bartolomé A., García-Santamaría M.T., et al. 2010. Age estimation obtained from analysis of octopus (Octopus vulgaris Cuvier, 1797) beaks: Improvement and comparisons. Fish. Res. 106: $171-176$ http://dx.doi.org/10.1016/j.fishres.2010.05.003

Rencher A.C. 2002. Methods of Multivariate Analysis, 2nd edition. John Wiley \& Sons, Inc, New York. http://dx.doi.org/10.1002/0471271357

Rocha F., Guerra A., González A.F. 2001. A review of reproductive strategies in cephalopods. Biol. Rev. 76: 291-304 http://dx.doi.org/10.1017/S1464793101005681

Rodhouse P.G. 2005. World squid resources. Review of the state of world marine fishery resources, FAO Tech. Rep. C2:175.

Ruiz-Cooley R.I., Ballance L.T., McCarthy M.D. 2013. Range Expansion of the Jumbo Squid in the NE Pacific: $\delta 15 N$ Decrypts Multiple Origins, Migration and Habitat Use. PloS One. 8(3): e59651.

http://dx.doi.org/10.1371/journal.pone.0059651

Sajina A.M., Chakraborty S.K., Jaiswar A.K., et al. 2011. Stock structure analysis of Megalaspis cordyla (Linnaeus, 1758) along the Indian coast based on truss network analysis. Fish. Res. 108: 100-105 http://dx.doi.org/10.1016/j.fishres.2010.12.006

Sánchez P. 1995. Age and growth of Illex coindetii. ICES J. Mar. Sci. 199: 441-444

Smale M.J., Clarke M.R., Klages N.T.W., et al. 1993. Octopod beak identification-resolution at a regional level (Cephalopoda, Octopoda: Southern Africa). S. Afr. J. Mar. Sci. 13(1): 269-293. http://dx.doi.org/10.2989/025776193784287338

Uchikawa K., Sakai M., Wakabayashi T., et al. 2009. The relationship between paralarval feeding and morphological changes in the proboscis and beaks of the neon flying squid Ommastrephes bartramii. Fish. Sci. 75(2): 317-323. http://dx.doi.org/10.1007/s12562-008-0036-2

Vega M.A., Rocha F.J., Guerra A., et al. 2002. Morphological difference between the Patagonian squid Loligo gahi populations from the Pacific and Atlantic Oceans. Bull. Mar. Sci. 71(2): 903-913

Villanueva R. 1992. Interannual growth differences in the oceanic squid Todarodes angolensis Adam in the northern Benguela upwelling system, based on statolith growth increment analysis. J. Exp. Mar. Biol. Ecol., 159(2): 157-177. http://dx.doi.org/10.1016/0022-0981(92)90034-8

Wang Y.G., Chen X.J. 1998. The current exploitation of cephalopod resources in the world and the development of Chinese distantwater squid jigging fisheries. J. Shanghai Fish. Univ. 7: 285287 (In Chinese with English abstract)

Wang Y.G., Chen X.J. 2005. The Resource and Biology of Economic Oceanic Squid in the World. Ocean Press, Beijing, pp. 79-295.

Wolff G.A. 1984. Identification and estimation of size from the beaks of 18 species of cephalopods from the Pacific Ocean. NOAA Technical Report NMFS 17: 1-50

Xavier J.C., Cherel Y. 2009. Cephalopod beak guide for the southern ocean. British Antarctic Survey Press, Cambridge, UK, 129 pp.

Xavier J.C., Clarke M.R., Magalhães M.C., et al. 2007. Current status of using beaks to identify cephalopods: III International Workshop and training course on Cephalopod beaks, Faial Island, Azores. Arquipélago 24: 41-48.

Xavier J.C., Phillips R.A., Cherel Y. 2011. Cephalopods in marine predator diet assessments: why identifying upper and lower beaks is important. ICES J. Mar. Sci. 68(9): 1857-1864. http://dx.doi.org/10.1093/icesjms/fsr103

Yatsu A. 2000. Age estimation of four oceanic squids, Ommastrephes bartramii, Dosidicus gigas, Sthenoteuthis oualaniensis, and Illex argentinus (Cephalopoda, Ommastrephidae) based on statolith Microstructure. Jpn. Agri. Res. Quart. 34: 75-80.

Yatsu A., Mori J. 2000. Early growth of the autumn cohort of neon flying squid, Ommastrephes bartramii, in the North Pacific Ocean. Fish. Res. 45: 189-194. http://dx.doi.org/10.1016/S0165-7836(99)00112-5

Yatsu A., Midorikawa S., Shimada T., et al. 1997. Age and growth of the neon flying squid, Ommastrephes bartrami, in the North Pacific Ocean. Fish. Res. 29: 257-270 http://dx.doi.org/10.1016/S0165-7836(96)00541-3

Yatsu A., Tanaka H., Mori J. 1998a. Population structure of the neon flying squid, Ommastrephes bartramii, in the North Pacific. In: Okutani T. (ed.), Contributed Papers to International Symposium on Large Pelagic Squids. Japan Marine Fishery Resources Research Center, Tokyo, pp. 31-48.

Yatsu A., Mochioka N., Morishita K., et al. 1998b. Strontium/calcium ratios in statoliths of the neon flying squid, Ommastrephes bartrami (Cephalopoda) in the North Pacific Ocean. Mar. Biol. 131: 275-282. http://dx.doi.org/10.1007/s002270050320 